\title{
Civic Education and the Reasonable Religious Citizen ${ }^{1}$
}

\section{La educación cívica y el ciudadano religioso razonable}

\author{
JAN HARALD ALNES \\ Department of Philosophy, UiT The Arctic University of Norway, Norway
}

\begin{abstract}
The purpose of the article is to refute Marc Ramsey's objections to principles of civic education based on political liberalism. I argue that Ramsey misconstrues the distinction between the public and the private sphere as it emerges from the point of view of political liberalism, and that his claim that, when scrutinized, political liberalism collapses into comprehensive or «autonomy» liberalism is unfounded. The significance of our theme is that education according to political liberalism is more tolerant than education according to comprehensive liberalism. Non-liberal reasonable religious parent might well endorse the former principles, but are likely to object to the latter ones.

\section{KEYWORDS}

CIVIC EDUCATION, JOHN RAWLS, MARC RAMSEY, POLITICAL LIBERALISM VS COMPREHENSIVE LIBERALISM, THE PUBLIC AND PRIVATE SPHERES
\end{abstract}

1 I am grateful to the inspiring audience at the conference «Ideas and Realities of Democracy» held at The Åland Islands Peace Institute, 26-27 September 2013. I am particularly thankful to Roar Anfinsen and Sia Spiliopoulou Åkermark for interesting and challenging comments. My talk contained reflections on both Marc Ramsey and Amy Gutmann, but Manuel Toscano and José María Rosales gave the friendly but firm advice that I better spell out my argument in two separate publications. This article, therefore, is to be followed up by an analysis of Gutmann's well-founded and influential reflections on education and democracy.

This article is part of The Civic Constellation project (Spain's National Research Fund, FFI2011-23388).

\footnotetext{
(C) Contrastes. Revista Internacional de Filosofia. Suplemento 20 (2015), pp. 95-112. ISSN: 1136-9922

Departamento de Filosofía, Universiad de Málaga, Facultad de Filosofía y Letras

Campus de Teatinos, E-29071 Málaga (España)
} 


\begin{abstract}
RESUMEN
El propósito de este artículo es refutar las objeciones de Marc Ramsey a los principios de educación cívica del liberalismo político. Argumento que Ramsey malinterpreta la distinción entre la esfera pública y la esfera privada que emana del liberalismo político, y que su opinión de que, cuando es escrutado, el liberalismo político deriva en un liberalismo comprehensivo o de la «autonomía» carece de fundamento. La relevancia del tema es que la educación de acuerdo con el liberalismo político es más tolerante que la educación conforme al liberalismo comprehensivo. Aquellos padres razonablemente religiosos que no son liberales podrán aceptar un liberalismo político, pero no uno comprehensivo.
\end{abstract}

PALABRAS CLAVE

EDUCACIÓN CÍVICA, ESFERAS PÚBLICA Y PRIVADA, JOHN RAWLS, LIBERALISMO POLÍTICO VS LIBERALISMO COMPREHENSIVO, MARC RAMSEY

\title{
I. INTRODUCTION
}

In philosophy we rely on distinctions all the time. Political philosophy distinguishes between the private sphere and the public sphere, or the sphere for individuality and self-realization and the sphere for law and governmental control, to mention the example relevant to our present topic. Such a dual distinction might be intended in radically different ways; it might be invoked as a useful analytical tool or it might be taken to correspond to a reality, and it might be sharp or gradual. A wrong take on the purpose and significance of a distinction, might lead to a misreading of a philosophical position; the reader might, for instance, underestimate its argumentative resources. My present aim is to defend civic or democratic education according to Rawlsian political liberalism against a common objection recently voiced in Marc Ramsey's «The Burdens of Judgment and Fallibilism» (Ramsey 2007). I argue that his way of reasoning fails in that it misconstrues the distinction between the private sphere and the public sphere as utilized in political liberalism. Ramsey's project misfires in that he does not show that political liberalism is incoherent. I further maintain that political liberalism implicates principles of civic education acceptable to some citizens who do not hold a liberal comprehensive doctrine, though, of course, not to all of them; this in opposition to the widespread standpoint of Ramsey which is hard to swallow for any citizen holding a nonliberal comprehensive doctrine.

In common with a number of influential philosophers of education, Ramsey seeks to demonstrate that political liberalism fails in that it is comprehensive liberalism in disguise; or, to be more precise, when its weak points stand cor- 
rected, political liberalism turns out to fall under autonomy liberalism. ${ }^{2}$ By «autonomy liberalism», I mean a political and moral theory that (1) bases its notion of the good on a philosophically controversial notion of autonomy and (2) invokes this notion when figuring out basic political or social principles. By relying on this general description, I avoid the tremendous task of considering the numerous alternative versions of autonomy liberalism to be found in the literature. And since Ramsey's position falls under this description, my discussion of his reasoning might be of some relevance when assessing other criticisms of political liberalism made from the same general perspective. In contrast, political liberalism does not rely on a debatable, non-political, notion of the good. ${ }^{3}$

Ramsey attempts to undermine political liberalism as such, but his views, as he himself realizes, are highly relevant to reflections on education:

Rawls argues that political liberalism calls for a much weaker conception of public education than that which autonomy liberalism appears to require $[\ldots]$ But if political liberalism fails, then autonomy liberalism's emphasis on the importance of critical reflection requires to us [sic] consider public education as a possible forum for the development of citizens' capacities for critical reflection (Ramsey $2007,151){ }^{4}$

I am about to argue (1) that Ramsey does not show that political liberalism fails, and (2) that the installing in the future citizens of the intended notion of critical reflection (see the next section) ought not to be an aim of the education within a contemporary constitutional democracy.

The structure is as follows. In Part II, I present Ramsey's criticism of Rawls and relate it to the private-public dimension. Part III is devoted to some aspects of Rawls's highly informed notion of the reasonable. These two discussions pave the way for another understanding of the burdens of judgment than the one affirmed by Ramsey. In part IV, I draw the consequence for the principles of civic

$2 \ll[\mathrm{My}]$ arguments support the general conclusion that political liberalism collapses into autonomy liberalism or comprehensive liberalism» (Ramsey 2007, 151; see also Callan 1997, Chapter 2.) The comprehensive liberalisms of Callan and Gutmann are versions of autonomy liberalism.

3 Throughout this article, «political liberalism» stands for «Rawlsian political liberalism». Some authors take the position of William Galston (see Galston 1991 and 1995) to be a version of political liberalism. I therefore need to underscore that I am in sharp opposition to his views on education; see Alnes 2014. In fact, my approach towards education is by far closer to that of Amy Gutmann, a leading defender of comprehensive liberalism.

4 See also Ramsey 2007, $166 f$. 
education in a constitutional democracy, also called «democratic education», that it must aim at teaching children to appreciate the burdens of judgment, and, as a part of this, introduce them to a variety of different and conflicting reasonable doctrines. This discussion is carried further in Part V, where I explicate both what it means to be a reasonable citizen and the education needed to ensure a future generation of reasonable citizens. Here I also suggest the way of drawing the private-public distinction according to political liberalism. I close off in Part VI by discussing the inescapable tension between the aim of a neutral democratic education ${ }^{5}$ and the teaching of history and culture.

As suggested, a deeply significant consequence of my claim that political liberalism embraces educational principles unavailable to autonomy liberalism is that it respects cultural diversity to a greater extent than comprehensive liberalism. Since we live in a complex, multicultural world, and our aim is to improve democracy so as to cope with this historically new, but on all counts permanent condition, I take this to be a decisive value of political liberalism against autonomy liberalism. I do not claim, however, that political liberalism favors neutral education. ${ }^{6}$ This becomes evident as we move along.

\section{THE GOOD AND THE PUBLIC-PRIVATE DISTINCTION}

Let us turn to Ramsey's way of setting up the distinction between the private and the public sphere and, in concordance with this, look at how he reaches the conclusion that «one must refute the standard liberal assumptions about the private character of critical reflection» (Ramsey 2007, 151). ${ }^{7}$ The critical reflection under consideration concerns one's understanding and approach towards one's notion of the good. Ramsey maintains that citizens ought to realize that their notion of the good is open to continuous revision and might even be false -in a word, they ought to endorse fallibilism. As Ramsey correctly observes, this understanding of the appropriate epistemic approach towards one's notion

5 «Neutral» here means «neutral between reasonable comprehensive doctrines».

6 See the specification in the former note; see also Gutmann 1995. The claim that political liberalism is restricted with respect to cultural diversity is forcefully argued in a number of articles by Stephen Macedo (Macedo 1995a, Macedo 1995b, Macedo 1995c). My general outlook on education is quite similar to that of Macedo, although we argue differently (see also Alnes 2014).

7 The aim of his paper is mainly negative, as he is unsure about exactly how the state should encourage critical reflection. He mentions the proposals of the early Jürgen Habermas, Will Kymlicka and Joseph Raz as promising candidates. 
of the good reaches well beyond the limits of political liberalism. (These limits are specified in the subsequent parts.) Without a widespread acceptance of fallibilism, Ramsey thinks, the best one could hope for is stability based on a mere modus vivendi and not stability for the right reason, i.e. due to a reasonable overlapping consensus. This is because citizens that have a non-revisable concept of the good, typically exemplified by people of strong monist religious commitments, tend to think that they have nothing to learn from fellow citizens who subscribe to conflicting doctrines. When someone believes that he has nothing to learn from fellow citizens, he tends to psychologize them, rather than pay due respect to the alternative, and in his view false, conceptions. This is a key-passage in Ramsey's way of reasoning:

Such confidence in one's own conception of the good cannot be reconciled with the idea that «reasonable disagreement» provides a sufficient reason for tolerating other conceptions of the good. If one has no doubt concerning his own conception, no inclination to think that there may be something to learn from others, it is difficult to see how he can regard rival conceptions as reasonable in any important sense. Without such doubts or concerns, our confidence leads easily to a disparaging view of others people's background experiences and beliefs. It becomes easy to see these background experiences and beliefs as corrupting or somehow tainted. How else could we regard experiences that lead otherwise reasonable and thoughtful agents away from our view of the good, which we endorse without any doubts? Confidence in the truth of our own view of the good may lead us to oppose social and political conditions that provide for these allegedly corrupt or tainted background experiences. Indeed this is how many religious conservatives regard issues such as homosexual family units (Ramsey 2007, 162f). ${ }^{8}$

In order to facilitate my treatment of this line of thought, let me reformulate Ramsey's reasoning. Our starting point is a given constitutional democracy dominated by reasonable disagreement among its citizens. Some of them hold a conception of the good not open to doubt or correction. As time goes by, some of these citizens begin to think that competing, false conceptions of the good prevail due to unfortunate experiences that lead away from the small and true path. This idea, in turn, makes them argue in favor of political arrangements and structures meant to shelter citizens from having such negative and damaging experiences. This argument presupposes that political liberalism makes a division between the public sphere and the private sphere along these lines: the

8 About the very last claim, see Rawls 2001, 163. 
fact of reasonable disagreement belongs to the former, whilst the notion of the good, and reflections upon it, belong to the latter. Ramsey's sound idea is that the notion of the good ought not to be separated from the reasonable in this way, as instability over time ensues. But, behold, this is not an appropriate way of understanding the separation between the reasonable and the good according to political liberalism. While Ramsey is correct in maintaining that the notion of the good, or more correctly, the comprehensive, or partial comprehensive doctrine into which it is embedded, reaches beyond the limits of political liberalism, it is not private or «non-political» in the sense that anything goes. It is of decisive importance to political liberalism to limit itself to reasonable comprehensive doctrines only. Thus, the notion of the reasonable, as it occurs in «reasonable disagreement» and «reasonable comprehensive doctrine», respectively, plays an irreducible role in both spheres. By itself, this observation strongly indicates that Ramsey's way of distinguishing between the spheres is misconceived. The problem, as will be demonstrated below, is that Ramsey's interpretation of Rawls's political liberalism does not take the full force of the key notion of reasonable disagreement into consideration. To be specific, and in explicit opposition to Ramsey, I shall argue that reasonable agreement do indeed provide sufficient reason for tolerating other conceptions of the good.

Now, despite being fallacious, Ramsey's argument shows something significant and illustrative. It makes it clear that as political liberalism does not speak to what and how we believe, or to our epistemic perspective on our notion of the good, given the limits set by the notion of the reasonable, it must provide strong substantial restrictions elsewhere. Otherwise, as Ramsey's way of reasoning demonstrates, the aim of stability for the right reasons is unjustified, and political liberalism would have to be classified as an unrealistic utopia. ${ }^{9}$ These restrictions are baked into the notion of the reasonable itself. On behalf of political liberalism, I shall provide two arguments against Ramsey's understanding of the notion of reasonable disagreement; one relates to content, the other to source. Both arguments are invoked in my assessment of Ramsey's example of the religious conservative who threatens the stability. Before presenting my arguments, however, I need to spell out some relevant aspects of the reasonable, with a particular emphasize on the notion of a reasonable comprehensive doctrine.

9 For an elaboration of political liberalism as a realistic utopia, see Rawls 1996, 54 and Rawls 2001, 4 and 13. 


\section{THE REASONABLE ACCORDING TO POLITICAL LIBERALISM}

In order to be a reasonable person, one must 1) hold a reasonable comprehensive doctrine, 2) accept the fact of reasonable pluralism and appreciate its sources, the burdens of judgment, and 3) be willing «to propose fair terms of cooperation and to abide by them provided others do» (Rawls 1996, 54). Taken together, these three conditions are sufficient, and all of them are necessary. ${ }^{10}$

We begin by looking at the content of reasonable comprehensive doctrines. «They have», says Rawls, «three main features». The first one is that it is

an exercise of theoretical reason: it covers the major religious, philosophical, and moral aspects of human life in a more or less consistent and coherent manner. It organizes and characterizes recognized values so that they are compatible with one another and express an intelligent view of the world (Rawls 1996, 59).

Such a doctrine organizes the fundamental moral aspects of life as well as systematizes one's values. In other words, it contains or expresses a person's conception of the good.

Rawls continues by observing that «each doctrine will do this in ways that distinguish it from other doctrines, for example, by giving certain values a particular primacy and weight». Now, two such reasonable doctrines, as we all know, might be in conflict in that their ordering of values differs, or their moral standards concerning particular acts are dissimilar. The second feature is that the «doctrine is also an exercise of practical reason», as values might come to stand in conflict, and a resolution be demanded. The third feature is that «it normally belongs to, or draws upon, a tradition of thought and doctrine [...] it tends to evolve slowly in the light of what, from its point of view, it sees as good and sufficient reason» (Rawls 1996, 59). Taken together, these three features are strikingly open-ended. No particular moral, existential or individual notion is introduced. The reason, as underscored above, is that political liberalism cannot engage itself in such subjects,

10 My formulation of the necessary and jointly sufficient conditions for being reasonable differs from Rawls's, as I present the holding of a reasonable comprehensive doctrine as a separate condition, while Rawls subsumes it under the burdens of judgment (Rawls 1996, 58-59 and 375). The reason is that Rawls wants to leave the comprehensive doctrines and their nonpolitical values out of political liberalism as much as possible, as political liberalism is to «leave philosophy as it is»; see the quote in note 13. As our theme is civic education, something not in the forefront of Rawls's mind, I draw the conditions differently. This difference is accordingly solely one of purposes and involves no criticism or attempt at improvement. 
but must stay as neutral as possible. ${ }^{11}$ But, this open-endedness makes it hard to see the relevance of such a doctrine to liberalism. Cannot a strictly authoritarian or elitist doctrine fall under Rawls' specification of a reasonable doctrine? Such a doctrine could be systematic (feature one), it could acknowledge conflict between values and thus need to invoke practical reason (feature two), and as the third feature involves a «normality-clause», the actual comprehensive doctrine need not be part of a tradition. As a response to this worry, Rawls adds a relational condition for a comprehensive doctrine to be reasonable, namely that it «does not reject the essentials of a democratic regime» (Rawls 1996, xviii). The importance of this condition is made clear in «The Idea of Public Reason Revisited»: «Comprehensive doctrines that cannot support [a constitutional] democratic society are not reasonable. Their principles and ideals do not satisfy the criterion of reciprocity, and in various ways they fail to establish the equal basic liberties» (Rawls 1999, 172f.). As demonstrated by this illuminating passage, the criterion of reciprocity, satisfied by all reasonable doctrines, is basic to political liberalism:

Citizens are reasonable when, viewing each other as free and equal in a system of social cooperation over generations, they are prepared to offer one another fair terms of cooperation according to what they consider the most reasonable conception of political justice; and when they agree to act on those terms, even at the cost of their own interests in particular situations, provided that other citizens also accept those terms. The criterion of reciprocity requires that when those terms are proposed as the most reasonable terms of fair cooperation, those proposing them must also think it at least reasonable for others to accept them, as free and equal citizens (Rawls 1999, 136f). ${ }^{12}$

The stress is on viewing each other as free and equal citizens. That is to say, the notions of freedom and equality have an exclusively political role in political liberalism and, as such, they are separated from metaphysical and broader moral considerations. Accordingly, the principle of reciprocity does not state how one should view each other and oneself from perspectives other than the political one. The principle has the consequence, however, that for a religious doctrine to be reasonable, it must be based on «an account of free faith» (Rawls

11 On notions of neutrality, see Rawls 1996, 190-195 and Costa 2004 and 2011, 60-64.

12 The passage continues thus: "Citizens will of course differ as to which conceptions of political justice they think the most reasonable, but they will agree that all are reasonable, even if barely so». This passage makes it clear that the overlapping consensus is about a family of conceptions of political justice, a family that includes justice as fairness. 
1996, 170). ${ }^{13}$ The crucial point is that a reasonable comprehensive doctrine need not embrace or endorse democracy, but must be in accordance with the weaker claim of not rejecting the criterion of reciprocity. It is clear, then, that the domain of reasonable comprehensive doctrines might be wider than that of reasonable comprehensive liberal doctrines (see Rawls 1996, xxxix). As Rawls observes, a non-liberal comprehensive doctrine «can still be compatible for the right reasons with a liberal political conception» (Rawls 1996, xxxix). ${ }^{14}$ From what we have said thus far, it is clear that from the perspective of political liberalism, civic education must be neutral in the sense of not favoring reasonable comprehensive doctrines, liberal or not; and this includes reasonable comprehensive versions of autonomy liberalism. In Rawls own words:

The problem of political liberalism is to work out a political conception of political justice for a constitutional democratic regime that a plurality of reasonable doctrines, both religious and nonreligous, liberal and nonliberal, may freely endorse [...] Emphatically it does not aim to replace comprehensive doctrines, religious or nonreligious, but intends to be equally distinct from both and, it hopes, acceptable to both (Rawls 1996, xl).

\section{Iv. THE SIGNIFICANCE OF THE BURDENS OF JUDGMENT}

Let us turn to Ramsey's take on the burdens of judgment. «The burdens», he says at the very beginning of his article, «allow us to see persons who disagree with our comprehensive moral commitments as reasonable agents who make diligent use of their moral powers [...] [they] ground liberal politics in the modest notion of reasonable disagreement» (Ramsey 2007, 150). Here we learn that it is a modest notion and that it enables us to realize that we might

13 Rawls formulates the general relationship between comprehensive doctrines and political liberalism thus: «Political liberalism abstains from assertions about the domain of comprehensive views except as necessary when these views are unreasonable and rejects all variations of the basic essentials of a democratic regime. This is part of leaving philosophy as it is» (Rawls 1996, 375). The point expressed in the final sentence is, of course, extremely important to our subject.

Although I shall not press this issue further, some might think that Rawls is a bit naïve when he states that «here I shall suppose - perhaps too optimistically- that, except for certain kinds of fundamentalism, all the main historical religions admit of such an account and thus may be seen as reasonable comprehensive doctrines» (Rawls 1996, 170).

14 For the invoked distinction between a doctrine and a conception, see Rawls 1996, 14, n.15, and Dreben 2003, 329f. 
disagree with reasonable persons. ${ }^{15}$ Let us next look at the presentation in the section entitled «The Burdens of Judgment». The section consists of two parts, a presentation of the burdens of judgment and then a treatment of its sources. This is the whole presentation:

The burdens of judgment allow us to see persons who disagree with us as responsible agents who develops their comprehensive views through the diligent exercise of their moral powers rather than as persons who are blind to obvious truths or just morally vicious. In accepting the burdens, we accept that it is unrealistic to expect that our society can be unified by a single comprehensive doctrine without resource to the coercive use of state power. The burdens encourage us to accept other persons for political purposes as having a legitimate interest in the pursuit of their own conceptions of the good. Moreover, it encourages us to regard them as agents who can be trusted to abide by fair terms of cooperation. Thus, the burdens reinforce the other elements of reasonableness (Ramsey 2007, 157f.). ${ }^{16}$

This understanding of the significance of the burdens of judgment is too weak. Ramsey's weak reading is further evident from the role he assumes it to play within political liberalism: «I suggest that we see the burdens of judgment as replacing liberal commitments to individuality and critical reflection $[\ldots]$ the burdens do say at least something about the good (the difficulty of reaching a consensus on it)» (Ramsey 2007, 157). Ramsey does not take into consideration the fundamental principal difference between the roles of the burdens of judgment within political liberalism and the critical reflections about the good in autonomy

15 Ramsey states, with no reference at all, that «Political liberalism encourages the naïve expectation that liberal principles can meet with an easy acceptance, even from very conservative religious perspectives» (Ramsey 2007, 151). Such expectations, I would argue, are encouraged by the misreading of political liberalism sought corrected here.

16 This is the list that Ramsey relates to:

«Reasonable persons:

1. (a) possess the two moral powers -the capacities for a sense of justice and for a conception of the good-; (b) possess the intellectual powers of judgment, thought, and inference; (c) have a determinate conception of the good interpreted in light of some comprehensive view; (d) are able to be normal, fully cooperative members of society over a complete life;

2. are ready to propose and willingly abide by principles and standards that are fair terms of social cooperation, given the assurance that others will likewise do so;

3. recognize the burdens of judgment;

4. have a reasonable moral psychology; and

5. recognize the five essential elements of a conception of objectivity» (Ramsey 2007, 157 -originally summarized thus by Wenar 1995, 37). 
liberalism. Liberal commitments to individuality and critical reflections are due to specific liberal conceptions about the good, and thus presuppose a comprehensive or partially comprehensive doctrine, or a set thereof, while in political liberalism, the burdens of judgment have the task of making sense of the fact of reasonable pluralism. This fact, in turn, is seen as an unavoidable outgrowth of the establishment of constitutional democracies in a complex and diverse modern world. The point about the burdens of judgment is not that it is difficult to reach a consensus about the good, but that even if such a consensus were to be realized, it would not last over time. And this, in turn, is due to the existence of enduring free institutions in the regime stipulated to have obtained the consensus.

Let me emphasize this point. The burdens of judgment relate to the working of the human mind -the human condition, so to speak-as it unfolds in the historically contingent conditions of our contemporary western regimes. Clearly, this might sound just like another grand theory, like that of Kant, Mill or Habermas, as Ramsey seems to think it is -to Ramsey, the point being that political liberalism is weaker than autonomy liberalism, and this is what brings it into trouble-. But, Rawls's point is exactly that this is not another such theory. Comprehensive or autonomy liberalism is based on the assumption that it is possible, in the long run, to reach an agreement about the value of autonomy or free choice. Political liberalism denies this. Normally, a defender of political liberalism subscribes to some or other reasonable comprehensive doctrine-Rawls, for instance, subscribes to justice as fairness- but despite this, he simultaneously accepts the fact that in general he cannot, by the use of reasonable arguments, persuade the holders of alternative reasonable comprehensive doctrines that he is right, and they wrong. ${ }^{17}$ The overlapping consensus, guaranteeing stability for the right reasons, is a consensus between reasonable citizens holding reasonable comprehensive doctrines (not necessarily liberal ones) that approach the good differently. These reasonable comprehensive doctrines cannot all be true, but still the reasonable citizens involved do take the other citizens to be reasonable as well.

Let us take a minute to specify what all this means. A reasonable disagreement between $A$ and $B$ means that both $A$ and $B$ are reasonable, that is, both accept the burdens of judgment and $A$ knows that $B$ accepts the burdens of judgment and $B$ knows that $A$ accepts the burdens of judgment. Consequently,

17 Here «justice as fairness» refers to the moral theory that consists of the two principles of justice together with the justification provided by Rawls 1971 (and slightly adjusted later). In Rawls's writings after he introduced the idea of political liberalism, «justice as fairness» refers to the two principles of justice alone. In this context, it is a member of a family of reasonable liberal conceptions of justice (see Rawls 1996, xlviiif., and Rawls 2001, 14. See also Dreben 2003, 320). 
both accept that the other has a reasonable conception of the good. Even though no specification of the good is involved, it is clear that a reasonable person according to the standards of political liberalism is reflective. As we have seen, Ramsey assumes that autonomy liberalism is stronger than political liberalism in that it accepts all the requirements about reasonableness held by the latter, but adds some further requirements in specifying interests related to the notion of the good (see Ramsey 2007, 157). According to the outlined account of the reasonable person, this is a seriously inappropriate description. One might be a devoted Kantian without being reasonable according to the strictures of political liberalism. That is, one might not only think that Kantianism in some version or another is true, but in addition, believe that the reason defenders of empiricism or naturalism, say, do not accept this is that they have misunderstood something or other. To Ramsey, this must be somewhat ironic, as there are both reasonable persons of faith and unreasonable defenders of autonomy liberalism. In sharp contrast to Ramsey's view, I hope to have made it clear that autonomy liberalism is not political liberalism plus some or other conception of the good.

As I see no reason to ascribe to Ramsey a trivial mistake, it might be that his reading is based on a simplified understanding of the source of reasonable pluralism, namely the burdens of judgment, which, in turn, leads him to misconstrue the notion of reasonable pluralism. So, let us move from content to source. In his account, Rawls gives a list of six complex explanations, ranging from $a$ to $f$, of the burdens of judgment (Rawls 1996, 56f.). This list includes varieties of equally rational ways of weighting evidence and an emphasis on the use of notoriously vague concepts; that is to say, it includes factors belonging to the use of both theoretical and practical reason. Rawls explicitly states that his list «covers only the most obvious sources» (Rawls 1996, 56). But, according to Ramsey -and here he relies heavily on Charles Larmore's The Morals of Modernity-,

the idea that our assessment of moral questions depends on our own experience, is the most crucial element of the burdens of judgment. For the most part, the other elements are either not distinctively moral, or else they are explained in terms of $d$ itself. ${ }^{18}$ While Rawls does not explicitly acknowledge the centrality of $d$, I believe that Larmore's analysis is faithful to Rawls's intentions (Ramsey 2007, 158).

18 This is $d .:$ «To some extent (how great we cannot tell) the way we assess evidence and weight moral and political values is shaped by our total experience, our whole course of life up to now; and our total experience must always differ. Thus, in a modern society with its numerous offices and positions, its various divisions of labor, its many social groups and their ethnic variety, citizens' total experiences are disparate enough for their judgments to diverge, at least to some degree, on many if not most, cases of any significant complexity» (Rawls 1996, 56f.; cited in Ramsey 2007, 158). 
Now, pace Ramsey, it is clear that Rawls's intention is exactly not to maintain that some of the listed (and unlisted) aspects are more central than the others. One reason for this is that any attempt at reducing the list of sources for the burdens of judgment to one or two fundamental sources, requires at a minimum a contested theory about the interrelationships between experience, including perception, and theoretical and practical reason. Or, expressed differently: political liberalism maintains that in general our assessment of moral questions depends on the interplay between experiences and a use of theoretical and practical reason that involve more or less vague concepts. A reductive theory would simply invite the burdens of judgment back in through the side door.

We have seen that an aspect of reasonableness is the acceptance of the burdens of judgment. This acceptance governs to a considerable degree how one views other citizens and human beings. It involves respecting them, and treating them as rational and reasonable even when one takes them to hold false or absurd beliefs. The very acceptance of the burdens presupposes familiarity with, and insights into, viewpoints differing from one's own. The consequence for democratic education should be evident: the students are to learn about a variety of comprehensive doctrines. We will return to some problematic points about this in the final part. Speaking with the communitarians, this acceptance, and the manner of relating to fellow human beings that goes with it, is an aspect of one's identity on line with cultural heritage and religious or philosophical doctrines. ${ }^{19}$

\section{IS THE RELIGIOUS CONSERVATIVE CITIZEN REASONABLE?}

Let us finally take a closer look at Ramsey's example of the religious conservative. Picture a reasonable religious conservative, that is, a person who is convinced both that his conception of the good is the right one and that he has nothing to learn from alternative conceptions of the good and accepts the burdens of judgment (among other things, see note 16). Ramsey seems not to realize that, given these conditions, the claim that «If one has no doubt concerning his own conception [...] it is difficult to see how he can regard rival conceptions as reasonable in any important sense» is vacuous. The point of his argument was to stipulate the very existence of such a reasonable person and argue that one obtains a fragile situation, and not a stable one. As we better not maintain both that this person is and is not reasonable, the difficulty that Ramsey uncovers,

19 See Rawls 2001, 199. Rawls attributes to Gutmann the point that the notion of identity cuts across the division between the political and the non-political. 
contrary to his own intensions, is that it is hard to imagine such a person. After all, Ramsey evidently thinks that a religious conservative of the envisaged kind cannot fully encompass the burdens of judgment. That might well be correct, but it does not amount to an argument against political liberalism. Such a person is namely excluded from political liberalism from the outset, as the overlapping consensus is established between reasonable citizens only.

If Ramsey's way of thinking is to have any bite, he must demonstrate that an acceptance of the burdens of judgment is unstable, and might easily be given up. I have suggested that to be reasonable is an aspect of one's identity, and is therefore a stable trait of a person. One does not normally or easily move away from respecting other citizens' reason and rationality to view their «background experiences and beliefs as corrupting or somehow tainted».

Let me note yet another point: If it is difficult to imagine that the conservative person of faith could also be reasonable, this uncovers something deep about the relationship between faith and reason; they hang intimately together. Rawls draws a distinction closely corresponding to the private-public distinction by separating communities, including the family, from the society. The latter is characterized by people subscribing to different and often sharply opposing comprehensive doctrines, while the former is characterized by an agreement on some notion or another of the good. The distinction relates to ways of using reason and argument, or, in Rawls's language, it is «a division of labor between different kinds of principles» (Rawls 2001, 165). But, one must never lose sight of the fact that it is the very same citizens, or future citizens, that belong to both communities and society.

As the debate among liberals on education has made clear, it might well be that the education for an appreciation of the burdens of judgment indirectly is an education against religious fundamentalism, in that one's political and non-political conceptions must be adjusted in light of each other, and reason is reason. ${ }^{20}$ In their influential writings on civic or democratic education, Gutmann and Eamonn Callan stress the potential conflict in the education provided by the community and society, respectively, and this might be a driving force of Ramsey's article as well. ${ }^{21}$ But Rawls is fully aware of the possibility of this conflict. He makes it clear that education according to political liberalism has

20 Macedo 1998 discussed the interrelationships between background culture and political principles. I find his discussion of the complexity of John Locke's conceptualization of toleration in the classic $A$ Letter on Toleration particularly illuminating. In short, Macedo endorses Locke's argument in favor of a separation between state and church and his view that the attitudes and values of moderate Christians support liberalism.

21 See Gutmann 1995, 576-579 and Callan 1997, Chapter 2. 
some fundamental similarities with education according to Kantian or Millian comprehensive principles (Rawls 1996, 199f). He realizes that one must expect that some pupils educated according to the strictures of political liberalism make the step from appreciating the burdens of judgment to viewing (moral) autonomy as a fundamental value. The cleavage in aim between the invoked principles of education is that while political liberalism leaves it to the children themselves to make, or not make, this step, autonomy liberalism requires the education to be geared towards making the children view themselves as autonomous. ${ }^{22}$ Expressed differently: political liberalism not only accepts, but appreciates the possibility that the complex education provided by the society and the community (including the family), sometimes pulling in different directions, leads the child to hold on to the faith of the community and at the same time accept the burdens of judgment. This child resists the move to moral autonomy. Autonomy liberalism, by contrast, takes moral autonomy to be the end-point of democratic education. It aims at installing in the child a critical perspective on the deepest commitments of his community.

\section{THE INESCAPABLE TENSION OF CIVIC EDUCATION}

Clearly, the state has a legitimate interest in the content of the education of its future citizens. It wants them to uphold, promote and reinforce the state with its present organization, constitution and fundamental political values and virtues. ${ }^{23}$ This is uncontroversial, and both autonomy liberalism and political liberalism are in agreement here. ${ }^{24}$ But, the state wants more. It also wants its future citizens to be familiar with the nation's history and its canons of literature and music: in a word, its culture. The education of all subjects, and this in particular, involves values (including virtues), ${ }^{25}$ and clearly, a number of these values go beyond the political one. This has the consequence that the education

22 I owe this way of formulating the point to discussions with Sia Spiliopoulou Åkermark.

23 Concerning the latter: «the virtues of political cooperation that make a constitutional regime possible are [...] very great values. I mean, for example, the virtues of tolerance and being ready to meet others halfway, and the virtues of reasonableness and the sense of fairness. When these virtues are widespread in society [...], they constitute a very great public good, part of society's political capital» (Rawls 1996, 157).

24 Gutmann takes the aim of democratic education to be conscious social reproduction (Gutmann 1999, 39-47).

25 For this Deweyan understanding of teaching, see Alnes 2014. 
tends to be conservative in preserving prevalent values, and the teaching, even when being in accordance with the statures of political liberalism, supports the values of the society's dominant comprehensive doctrine or doctrines. Political liberalism is aware of this, as is clear from the third characteristic of a reasonable doctrine, which, to repeat, is that «it normally belongs to, or draws upon, a tradition of thought and doctrine [and] it tends to evolve slowly» (Rawls 1996, 59; cited in Part II). This conservativeness is clear also from the very starting-point of political liberalism. It takes itself to be the result of a historical contingent process and to spell out conceptualizations and values that are implicit in our contemporary western cultures ${ }^{26}$ Two points are important here: first, the educational ideals must take contingent factors into consideration. This means that the education cannot be completely neutral with respect to all the reasonable comprehensive doctrines represented in a society, as some of them are more deeply embedded in its culture. ${ }^{27}$ But, clearly, the education must seek neutrality. This tension is inescapable, and the way of coping with it may vary from case to case. A clear awareness among the reasonable citizens and their elected political leaders about the educational ideal of neutrality concerning prevailing values and virtues that go beyond the political ones, is the only guarantee that biased, often well-established, education -that is, education in favor of some reasonable doctrines at the cost of other equally reasonable doctrines- might be disputed and corrected. Clearly, both the complaint and the correction must be made from the perspective of public reason and the law makers must be reasonable, as this notion has been used here.

The second point is that despite varieties in history and culture among contemporary constitutional democracies, their respective citizens share cor-

26 On this point, see for instance Rawls 1996, xxvi and 14-15. Burton Dreben formulates the starting point of Rawlsian political liberalism thus: «Rawls always begins in mediis rebus, quite explicitly so. You start with intuitive moral, political considerations, and then you see what they come to. You cannot ground them» (Dreben 2003, 322).

$27 \mathrm{We}$ are at the border of a number of complex issues about minority rights. The position called liberal egalitarianism, for instance, maintains that «As the state institutions - public policies, school curriculum, national holidays- are always culturally biased, reflecting the cultural norms and practices of the dominant culture, this puts members of minorities in an unequal position compared to the majority» (Vitikainen forthcoming, Chapter 4; see also Kymlicka 1995, Chapter 6). Political liberalism is concerned with a number of equality issues, also this one, but it qualifies the generality of the claim. Since it takes the aim of democratic education to be the education of future citizens-i.e. future reasonable individuals - minorities cannot, under normal circumstances, expect support if they favor an education in conflict with this principle-. Thus, political liberalism does not accept that an education with this purpose is unjustifiably biased. This topic-toleration within the limits of the reasonable- is discussed in Alnes 2014. 
responding reasonable comprehensive doctrines as well as overlapping political values and virtues. This opens up the possibility of international regulations and courts to give verdicts in cases of accusations of biased public education (including the use of loaded symbols), in favor of widespread and powerful reasonable comprehensive doctrines. The European Court of Human Rights, for instance, has been brought in to resolve such complaints. ${ }^{28}$ Let us end with the obvious: the public debate between elected leaders and reasonable citizens, and the rulings of the relevant national and international courts, must settle such controversies, not political liberalism. But, the principles of political liberalism must be the basis for the debate and the verdict. ${ }^{29}$

\section{REFERENCES}

ALNES, JAN HARALD. 2014: «Democratic Education and Reasonable Pluralism». In Alnes, J. H. and M. Toscano, eds., Varieties of Liberalism. Newcastle: Cambridge Scholars Publishing, 70-89.

CALLAN, EAMONN. 1997: Creating Citizens: Political Education and Liberal Democracy. Oxford: Clarendon Press.

DREBEN, BURTON. 2003: «On Rawls and Political Liberalism». In Freeman, S., ed., The Cambridge Companion to Rawls. Cambridge: Cambridge University Press, 316-348.

F囚LLESDAL, ANDREAS. 2015: «Religion and the State. The 'Lautsi' Case of the European

Court of Human Rights about Crucifixes in Italian Class Rooms». In Glaser, Hennig (ed.) Political and Religious Communities. Baden Baden: Nomos.

GALSTON, WILliAM. A. 1991: Liberal Purposes. Cambridge: Cambridge University Press.

GALSTON, WILLIAM. A. 1995: «Two Concepts of Liberalism». Ethics, 105: 516-34.

GUTMANN, AMY. 1995: «Civic Education and Social Diversity». Ethics, 105: 557-579.

28 Føllesdal (2015) lists a number of such cases.

29 This part could be read as a response to instructive comments by Tomasz Jarymowicz and Annamari Vitikainen on my talk «Political Liberalism, Civic Education and the Reasonable Nonliberal Citizen» at the Workshop «Pluralism, Democracy and Justice», UiT The Arctic University of Norway, December 5, 2013. 
GUTMANN, AMY. 1999: Democratic Education, second edition. Princeton: Princeton University Press.

HONNETH, ALEX. (forthcoming). «Education and the Democratic Public Sphere». In Jakobsen, J. and O. Lysaker, eds., Recognition and Freedom: Alex Honneth's Political Thought. Leiden: Brill.

KYMLICKA, WILL. 1995: Multicultural Citizenship: A Liberal Theory of Minority Rights. Oxford: Clarendon Press.

MACEDO, STEPHEN. 1995a: «Liberal Civic Education and Religious Fundamentalism: The Case of God v. John Rawls». Ethics, 105: 468-496.

MACEDO, STEPHEN. 1995b: «Multiculturalism for the Religious Right? Defending Liberal Civic Education». Journal of Philosophy of Education, 29: 223-238.

MACEDO, STEPHEN. 1995c. «Liberal Civic Education and Its Limits». $\mathrm{Ca}$ nadian Journal of Education, 20: 304-314.

MACEDO, STEPHEN. 1998: «Transformative Constitutionalism and the Case of Religion». Political Theory, 26: 56-80.

RAMSEY, MARC. 2007: «The Burdens of Judgment and Fallibilism». Contemporary Political Theory, 6: 150-174.

RAWLS, JOHN R. 1971: A Theory of Justice. Cambridge, Mass.: Harvard University Press.

RAWLS, JOHN R. 1996: Political Liberalism, paperback edition. New York: Colombia University Press.

RAWLS, JOHN R.1999: The Law of Peoples with «The Idea of Public Reason Revisited». Cambridge, Mass.: Harvard University Press.

RAWLS, JOHN R. 2001: Justice as Fairness: A Restatement. Cambridge, Mass.: The Belknap Press.

VITIKAINEN, ANNAMARI: forthcoming. The Limits of Liberal Multiculturalism. Basingstoke: Palgrave Macmillian.

WENAR, LEIF. 1995: «Political Liberalism: An Internal Critique». Ethics, 106: 32-62. 